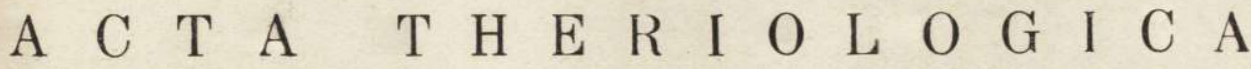

VOL. VI, 3 .

\section{The Occurrence \\ of Wormian Bones (Ossicula wormiana) in Some Mammals}

\section{Występowanie kostek Worma (Ossicula wormiana) u niektórych ssaków}

[with 5 tables and 2 figs.]

I. Introduction + _ + _ + . + . . . 33

II. Terminological questions . . . . . . . . . . . . . 34

III. Material and methods . . . . . . . . . . . . . 34

IV. Variations in the occurrence of Wormian bones in different species . . $\quad 35$

1. General remarks . . . . . . . . . . . . 35

2. Analysis of some species . . . . . . . . . . 36

V. Morphology and localisation of the Wormian bones . . . . 39

VI. Other anomalies in the sutures of the brain-case . . . . . . 46

VII. Discussion of results . . . . . . . . . . . . . 46

VIII. Summary 49

References . . . . . . 49

Streszczenie . . . . . . . . . . . 50

\section{INTRODUCTION}

The sutural bones were described as long ago as the 16 th century, when $\mathrm{P}$ a $\mathrm{r}$ acelsus discovered them in the human skull, and termed them "Ossicula anti-epileptica". From this time onwards many authors have reported the occurrence of supernumerary bones in skulls both of humans and of many species of other mammals, giving them various names: L'os de Bertin, oss. verticis triangulare, os interfrontale, os fonticuli-frontalis, os interparietale anterior, os bregmaticum, etc. Data on the occurrence of these bones in the skulls of mammals were collected together in 1923 by Schultz. Recently several works have been published discussing the Wormian bones in other soecies (V i rk ki, 1954; M a $\mathrm{nville,} \mathrm{1959).}$

Judging by the materials collected together in Schultz's work and in special 
publications, these elements have only been examined in the easily accessible species of large and medium-sized mammals. The majority of Micromammalia, undoubtedly on account of the lack of suitable craniological material, have escaped observation. In order to have a complete picture of the problem, however, it is worth while bearing in mind the frequency of occurrence of the Wormian bones in all groups of mammals. This may perhaps make it possible to find an explanation of their function and significance in the architectonics of the skulls of these animals.

The present publication is intended: 1 . to fill this gap, chiefly in relation to small and also larger mammals hitherto not examined, and 2. to compare the data of former authors on the basis of numerous series of craniological material from extensive geographical areas.

\section{TERMINOLOGICAL QUESTIONS}

The name Wormian bones (Ossicula wormiana, ossa suturarum) now covers different supernumerary bones occurring in sut. sagittalis, sut. parieto-interparietalis, sut. coronalis and in font. anterior and posterior. Judging, however, by textbooks ( $\mathrm{P}$ o p l e w sk i, 1949; K o p s c h, 1955) and the special works referred to here, the terminology of these bones has not as yet been established. In order to avoid misunderstanding, I should like to state precisely which elements will be dealt with in the following work.

It is necessary to distinguish: 1. Wormian bones (Ossicula wormiana), and 2. Ossa intercalaria, included by certain authors with the sutural bones (P oplews ki, l. c.).

1. Oss. wormiana may occur: a) in the sutures as sutural bones - ossa suturarum (in German - "Nahtknochen") or b) in the fontanelles, as fontanelle bones ("bregmatic bones", "fontanelle bones", "Fontanellknochen").

Their essence and genesis are of course the same. They differ only as to situation, which is not infrequently extremely difficult to define precisely.

2. Ossa intercalaria - these are separated bones within the limits of other component elements of the brain case and have nothing in common with sutures. K o p s h (1955) defined them by the term "Schaltenknochen", which is used, in my opinion incorrectly, by V ir k k i (1954) for the Wormian bones also.

In the following work only the Wormian bones will be dealt with, in the meaning including both fontanelle and sutural bones.

\section{MATERIAL AND METHODS}

A total of 6706 specimens was examined, belonging to 5 orders and 29 species of mammals (Table 1). The material came from the collection in the Mammals Research Institute of the Polish Academy of Sciences at Białowieża, the Cracow Branch of 
the Zoological Institute of the Polish Academy of Sciences, the Zoological Institute in Warsaw, the Animal Anatomy Institute of the Central College of Agriculture and the Zoological Museum of the Lomonosov State University in Moscow (LSU), and the Zoological Institute of the Soviet Academy of Sciences in Leningrad. The collections consisted of specimens from Poland, the Soviet Union and the Balkans.

The percentage of individuals of each species which possessed sutural bones was established, and any other anomalies recorded (additional sutures, fontanelle not closed). Measurements of the sutural bones was made by means of a vernier, usually under a stereomicroscope on account of the smallness of these elements.

In the majority of the species of mammals examined the sutures of the braincase do not ossify and are clearly visible. The whole material was therefore taken into consideration, while for example, in the case of Sciurus vulgaris Linna e u 1758 or Sus scrofa Linnaeus 1758 , or Lepus europaeus Pallas 1778 , in which the sutures with increasing age change into osseous adhesions, calculation was made of the percentage in relation to those specimens in which the sutures were clearly visible. In a few cases calculations were given in relation to the whole of the material of a given species examined.

In many cases therefore the data obtained are approximate and intended as a guide only, nevertheless they throw a certain light on the occurrence of sutural bones in different species of mammals.

\section{VARIATIONS IN THE OCCURRENCE OF WORMIAN BONES IN DIFFERENT SPECIES}

\section{General remarks}

The data set out in table 1 makes it possible to conclude that the occurrence of Wormian bones in the mammals examined is not even in character. In some forms these elements occur, while in others, despite the fairly numerous series of material, they were not found to be present [e.g. in Citellus suslicus (G üldenstaedt 1770), Pteromys volans (L inn a e s 1758), Muscardinus avellanarius (L in nae us 1758), Apodemus flavicollis (M e l chior 1834), Arvicola terrestris (L i n n a e u s 1758)]

It would seem that this phenomenon has no connection with systematic appurtenance. It should rather be connected with the morpho-functional properties of the skull and in many cases, also with the earlier or later ossification of the fontanelle and sutures in ontogenetic development.

With those forms in which the presence of Wormian bones was established, the percentage of individuals possessing them varies considerably (table 1). It may fluctuate within limits from $0.6 \%$ in Mus musculus, $1-5 \%$ in Talpa europaea, Lepus europaeus, Oryctolagus cuniculus, Sicista betulina, Apodemus agrarius, Microtus oeconomus, M. arvalis or Sus scrofa, to $17 \%$ in Sciurus vulgaris, about $22 \%$ in Dyromys nitedula, to as much as $58 \%$ in Erinaceus europaeus. The range of variation is even greater here than is apparent from the material at my disposal. It is well 
Table 1.

Occurrence of Wormian bones in different species.

\begin{tabular}{|c|c|c|c|c|}
\hline Species & Region \& locality & $\mathrm{N}$ & $\mathrm{n}$ & $o_{0}^{\prime}$ \\
\hline \multicolumn{5}{|l|}{ INSECTIVORA } \\
\hline Talpa europaea & Poznań district, Białowieża & 280 & 6 & 2.14 \\
\hline Erinaceus europaeus & $\begin{array}{l}\text { Polesie (BSSR), Białowieża, } \\
\text { Warsaw district }\end{array}$ & 52 & 30 & 57.69 \\
\hline \multicolumn{5}{|l|}{ LAGOMORPHA } \\
\hline Lepus europaeus & Poznań district & $\begin{array}{c}208 \\
(707)\end{array}$ & $\begin{array}{c}5 \\
(5)\end{array}$ & $\begin{array}{r}2.31 \\
(0.85\end{array}$ \\
\hline Oryctolagus cuniculus & Poland & 142 & 4 & 2.81 \\
\hline \multicolumn{5}{|l|}{ RODENTIA } \\
\hline Sciurus vulgaris & USSR, and Poland & 2037 & 354 & 17.38 \\
\hline Citellus suslicus & Lublin district & 396 & - & - \\
\hline Pteromys volans & USSR & 78 & - & - \\
\hline Muscardinus avellanarius & BSSR, Tulske Zasieki, Poland & 111 & - & - \\
\hline Eliomys quercinus & USSR and Poland & 48 & - & - \\
\hline Glis glis & USSR, Poland and Bulgaria & 140 & 1 & 0.71 \\
\hline Dyromys nitedula & USSR and Poland & 373 & 81 & $21.7 \mathrm{i}$ \\
\hline Sicista betulina & Białowieża & 141 & 3 & 2.13 \\
\hline Mus musculus & Białowieża & 474 & 4 & 0.63 \\
\hline Rattus rattus & BSSR (Polesie, Vilnius) & 106 & 11 & 10.38 \\
\hline Rattus norvegicus & Białowieża & 20 & - & - \\
\hline Apodemus flavicollis & Białowieża & 219 & - & - \\
\hline Apodemus sylvaticus & Polesie (BSSR) & 67 & - & - \\
\hline Apodemus agrarius & Polesie (BSSR) & 57 & 1 & 1.75 \\
\hline Microtus agrestis & Białowieża & 302 & 16 & 5.30 \\
\hline Microtus oeconomus & Białowieża, Polesie & 146 & 2 & 1.37 \\
\hline Microtus arvalis & Białowieża, Polesie, Wrocław & 463 & 32 & 4.97 \\
\hline Arvicola terrestris & Polesie, Białowieża & 194 & - & - \\
\hline \multirow{2}{*}{\multicolumn{5}{|c|}{$\begin{array}{l}\text { CARNIVORA } \\
\text { Mustelidae (Meles meles, } \\
\text { Mustela nivalis, M. puto- }\end{array}$}} \\
\hline & & & & \\
\hline $\begin{array}{l}\text { rius, Martes sp.) } \\
\text { Canidae (C. lupus, }\end{array}$ & Poland & 45 & 2 & 4.44 \\
\hline V. vulpes) & Poland & 19 & 1 & 5.20 \\
\hline ARTIODACTYLA & & & & \\
\hline Sus scrofta & Białowieża & 90 & 2 & 2.22 \\
\hline Total & & 6706 & 545 & \\
\hline
\end{tabular}

known that $0.6 \%$ of individuals with these bones were found among 13,000 human skulls ( $\mathrm{c}$ c h u l t z, 1923), 47\% in horses (M ülle r, 1937), $54 \%$ in Castor canadensis and $80 \%$ in Erinaceus europaeus (data given by $\mathrm{Sch}$ c l t z, l.c.).

\section{Analysis of some species}

In several cases the material of a given species was sufficiently numerous, and in addition came from so many different parts of its geographical range, that it proved possible to investigate the influence of 
the geographical zone on the occurrence of the Wormian bones. Analysis was made of two species: Dyromys nitedula and Sciurus vulgaris.

$$
\text { a. Dyromys nitedula (P a } 11 \text { a s 1779) }
$$

Generally speaking, in the whole material of this species $(n=372)$ Wormian bones occur in $21.5 \%$ of the specimens. In different populations they were, however, found in $68.75 \%$ of the individuals (Table 2). These

Table 2 .

Occurrence of Wormian bones in different populations of Dyromys nitedula.

\begin{tabular}{|c|c|c|c|}
\hline Region & $\mathrm{N}$ & $\mathrm{n}$ & $\%$ \\
\hline $\begin{array}{l}\text { 1. Białowieża Primeval Forest } \\
\text { including: a. Białowieża National Park } \\
\text { b. BSSR } \\
\text { 2. European part of USSR (Districts: Voronezh, Voro- } \\
\text { shilovgrad, Kharkov, Poltava, Kazan, and Volsk, Mol- } \\
\text { davia) } \\
\text { 3. Tatra Mts. (Poland) } \\
\text { 4. Caucasus (Azerbaijan, Armenia, Krasnodar, Pyati- } \\
\text { gorsk, Daghestan, Stavropolski Region, Caucasian } \\
\text { National Park, Don District, Nalchik) } \\
\text { 5. Central Asia (Kazakhstan, Alma-Ata, Vernyj, Ala-Tau) } \\
\text { 6. Martino collection (Balkans?) } \\
\text { 7. Transcaspia District, Tien-Shan, Kirgizia, Aleksand- } \\
\text { rovski ridge }\end{array}$ & $\begin{array}{r}170 \\
77 \\
15 \\
\\
8\end{array}$ & $\begin{array}{r}29 \\
3 \\
- \\
-\end{array}$ & $\begin{array}{r}17.06 \\
3.90 \\
- \\
-\end{array}$ \\
\hline Total & 372 & 80 & 21.50 \\
\hline
\end{tabular}

differences are evident even in materials from areas situated close to each other, e.g. in the Białowieża National Park these bones were found in $58 \%$ of the individuals, and in the eastern part of the Białowieża Primeval Forest (BSSR) in $75 \%$ of the individuals of this species. The numbers of specimens examined are not, it is true, very great, but the different degree of occurrence of Wormian bones within the whole geographical range of this species would seem to be a real phenomenon.

Table 2 shows the dependence of the percentage of skulls with these bones on the geographical latitude. The highest concentration of this feature is observed in specimens from the Białowieża Primeval Forest, and therefore from an area which in my material lies furthest to the north $\left(\varphi=\right.$ circa $\left.53^{\circ}\right)$. Further to the south this percentage gradually decreases to 3.9 for Kazakhstan (Alma-Ata, Ala-Tau, $\varphi=43-45^{\circ}$ ) and falls even to zero in material from the Balkans and Kirghiz $\left(\varphi=40-42^{\circ}\right)$.

A similar distribution, but not so distinctly marked, can be seen in 
M a n ville's materials (l.c.) on Lynx rufus ( $\mathrm{S} \mathrm{chreber} \mathrm{1777).} \mathrm{In} \mathrm{the}$ more southerly states of North America (Virginia) the concentration of bregmatic bones was higher ( 44 and $37.5 \%$ ) than in the state of Texas $(7.0 \%)$, although it is situated further to the south. Similar differences were present in material from the states of Oregon and Nevada.

Table 3 .

Occurrence of fontanelle bones in different populations of Sciurus vulgaris.

\begin{tabular}{|c|c|c|c|}
\hline Locality & $\mathrm{N}$ & $\mathrm{n}$ & $o$ \\
\hline $\begin{array}{l}\text { 1. Kola Peninsula, Arkhangelsk, Komi ASSR, Pechora } \\
\text { National Park }\end{array}$ & 50 & 5 & 10.00 \\
\hline $\begin{array}{l}\text { 2. Kondo-Sosvinski National Park, lower reaches } \\
\text { of River Ob }\end{array}$ & 37 & 8 & 21.62 \\
\hline 3. Yakutsk District & 148 & 20 & 13.51 \\
\hline 4. River Kolyma & 230 & 48 & 20.87 \\
\hline 5. Kamchatka & 3 & 2 & \\
\hline 6. Poland & 63 & 10 & 15.87 \\
\hline 7. Białowieża Primeval Forest (BSSR) & 112 & 18 & 16.07 \\
\hline $\begin{array}{l}\text { 8. BSSR, and Districts: Leningrad, Vladimirsk, Kalinin, } \\
\text { Novgorod }\end{array}$ & 115 & 11 & 9.56 \\
\hline 9. Moscow District & 118 & 15 & 12.71 \\
\hline 10. Powolzhe (Samara and Gorki Districts) & 52 & 5 & 9.62 \\
\hline 11. Ryazan, Voronezh and Kursk Districts & 20 & 7 & 35.00 \\
\hline 12. The Urals & 25 & 2 & 8.00 \\
\hline 13. Bashkir ASSR-National Park & 73 & 11 & 15.06 \\
\hline $\begin{array}{l}\text { 14. Krasnoyarsk Region, Turukhansk Region, Tomsk } \\
\text { District }\end{array}$ & 347 & 64 & 18.44 \\
\hline 15. Altai & 210 & 47 & 21.46 \\
\hline 16. Baikal, Trans-Baikal, Irkutsk District & 125 & 32 & 25.60 \\
\hline 17. Mongolia, Sayan National Park, Tubinsk District & 78 & 14 & 17.95 \\
\hline 18. Great Shantar & 25 & 9 & 36.00 \\
\hline 19. Amur Region & 68 & 7 & $10 .: 9$ \\
\hline 20. Primorski Region & 45 & 6 & 13.33 \\
\hline 21. Sakhalin & 10 & - & - \\
\hline $\begin{array}{l}\text { 22. Ukraine SSR (Crimea, Trans-Carpathians, Carpathians, } \\
\text { and districts: Poltava, Kiev, Chernovitsy; Moldavia) }\end{array}$ & 48 & 13 & 27.08 \\
\hline 23. Kazakhstan (S. v. exalbidus) & 26 & - & - \\
\hline Total & 2037 & 354 & 17.36 \\
\hline
\end{tabular}

b. Sciurus vulgaris Linnae us 1758

Material from this species comes from the extensive areas of the Soviet Union and from Poland, and includes many of the subspecific forms distinguished. I shall not enter further into so far-reaching a systematic question, but shall confine myself to defining specific appurtenance.

Over this area a different concentration of individuals possessing bregmatic bones was found in different populations, from 8.0 to $36.0 \%$, with an average for the whole material $(n=2037)$ of $17.38 \%$. Differences in the concentration of this feature in different populations of squirrels are 
statistically significant ( $\chi^{2}$ per homogeneity of binomial series). It was difficult to observe a regular distribution here (Table 3 ).

It is worth while mentioning that squirrels from Northern Europe (the Kola Peninsula, the Arkhangelsk Region, the Leningrad, Kalinin, Novgorod districts), have a very similar concentration of Wormian bones to that given by Virkki (1955) for squirrels from Western Finland (i.e. $9-10 \%)$.

The occurrence of bregmatic bones was not established in $S$. vulgaris from Sakhalin and Kazakhstan. In view of the small series of material this is not probably a proof that this feature does not occur at all, nevertheless from the theoretical aspect this percentage for $S$. $v$. exalbi. dus should be less than 4 .

\section{MORPHOLOGY AND LOCALISATION OF THE WORMIAN BONES}

An analysis was made of variation in shapes, dimensions and localisation of the Wormian bones in the skulls of the species of mammals studied. Index $\mathrm{K}$ was used to express shape, being the quotient of the maximum length and maximum breadth of the bone or group of bones occurring in one place. The relative size of the bones was defined by index W, calculated for purposes of guidance from the ratio of mean condylobasal length and arithmetical mean of the maximum length of the Wormian bone. The mean averages of $\mathrm{Cb}$.-length were used for these calculations, given according to measurements of the series of material examined or in certain cases, from literature. Detailed data are set out in table 4.

1. Talpa europaea Linna e us 1758 . The presence of these bones was established in 6 individuals $(2.14 \%)$, in 3 cases lying in the font. anterior, and in the remaining - in the font. posterior. These were usually single elements, of irregular shape, oval or in the form of an elongated spindle, measuring $0.7 \times 0.4 \mathrm{~mm}$. to $2.04 \times 0.86 \mathrm{~mm}$. (the maximum length is always given first, and the maximum breadth in the second place). In one case three bones were found lying in the font. anterior in the form of an elongated spindle $(4.4 \times 0.84 \mathrm{~mm}$.).

2. Erinaceus europaeus L in n e us 1758 . The number of individuals with these bones is $-\mathrm{n}=30(=57.69 \%)$. The bregmatic bones, from $1-4$ in number, always occurred in the font. anterior or in its immediate vicinity - in sut. sagittalis, above or below the place of contact of this suture with the sut. coronalis. These are usually relatively large formations, taking the form of a falling droplet, a spindle (coefficient $\mathrm{K}=$ above 4) or possible a triangle or rhomb. If there is more than one bone, then we find one large and $2-3$ relatively small bones. Usually the greater 


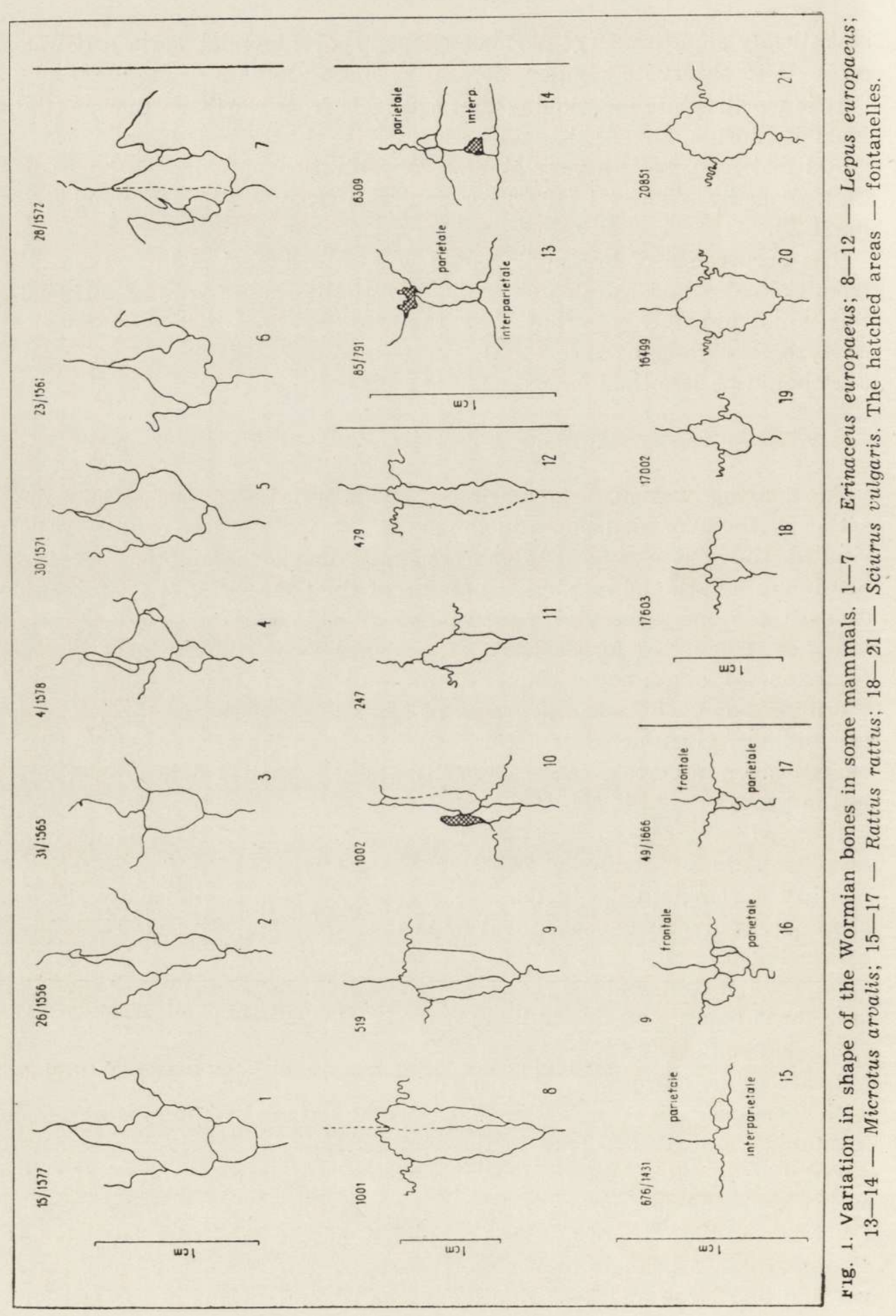


part of the bone lies towards the posterior of sut. coronalis (Fig. 1, 1-7).

3. Lepus europaeus $\mathrm{Pall}$ as 1778 . Single or paired forms were observed in the hare. The single ones were situated medially, in the bregmatic region, below sut. coronalis. The paired bones were situated similarly, but on both sides of sut. sagittalis. Neither of the two parts was symmetrical in shape and their dimensions varied. In one case they were observed to be set in almost vertical order. The left bone lay towards the posterior in relation to sut. coronalis, and the right towards the front (Fig. 1, 8-12). Certain parts of the suture separating the bones from the bones of the brain case were observed to be partially fused. Generally speaking these were relatively large bony elements $(W=7.2)$ clearly visible to the naked eye, their shape being fairly elongated (index $\mathrm{K}=$ $=3.4$ ).

4. Oryctolagus cuniculus ( $\mathrm{L}$ innaeus 1758). The sutural bones of rabbits were very similar in shape and dimensions to those observed in hares. In all 4 cases they lay in the sagittal suture, to the back of sut. co-
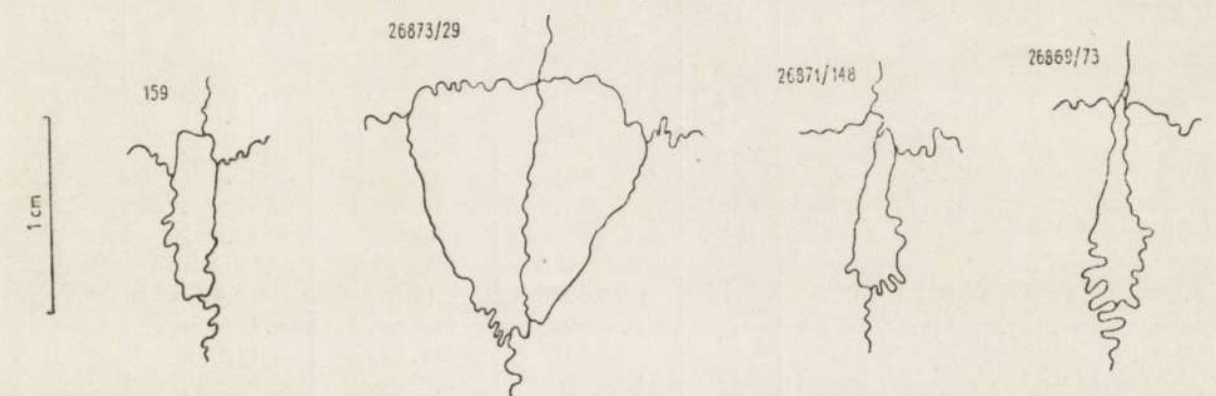

Fig. 2. Variation in shape of the Wormian bones in Oryctolagus cuniculus.

ronalis (Fig. 2). The shape in three cases was strongly elongated, spindle - or pear-shaped (coefficient $K=3.29$ ). These bones were of the same order of size as those in hares (coefficient $\mathrm{W}=7.00$ ).

The shape of the bones in individual no. coll. 26873/29 differed from the description given above for the remaining three. These were two bones separated by the sut. sagittalis, oval in shape, with joint dimensions for the whole group of $12.6 \times 11.0 \mathrm{~mm}$.

5. Sciurus vulgaris L in $\mathrm{n}$ a e u $\mathrm{s} 1758$. The dimensions of the Wormian bones were examined in squirrels from two series, from Kolyma and from Poland (Table 4). Differences were found here in the dimensions of these elements in individuals from the two above-mentioned areas. In material from the valley of the River Kolyma the Wormian bones are smaller than those in squirrels in Poland. These are in fact relatively large bones (average $3-5 \mathrm{~mm}$. long and $1.5-3 \mathrm{~mm}$. broad; index $\mathrm{W}=$ $=10.0)$, usually twice as long as they are broad $(K=1.9-2.2)$. The shape 
is usually irregular and in principle in accordance with the description given by V i r k k i (1954) - Fig. 1, 18-21. It is an interesting fact that in squirrels from Finland the bregmatic bones are almost twice as small as those from Poland. Their dimensions on the average are $3.3 \times 1.6 \mathrm{~mm}$. and $4.9 \times 2.8 \mathrm{~mm}$. It is possible that this is a property of populations living in northern territories.

6. Glis glis ( $\mathrm{L}$ in n a e u 1766 ). The material examined comes chiefly from the European part of the Soviet Union, the Caucasus, the area beyond the Caucasus and Dagestan $(N=133)$. Not one skull was found with Wormian bones in this series. Only in a small series of edible dormice in Bulgaria $(n=5)$ was one bone found. It is relatively large $(5.8 \times$ $\times 1.7 \mathrm{~mm}$.) and lies in the sut. sagittalis in the font. posterior region.

Table 4.

Dimensions of Wormian bones in some species of mammals.

\begin{tabular}{|c|c|c|c|c|c|}
\hline Species & $\mathrm{N}$ & $\begin{array}{l}\text { Max. } \\
\text { length }\end{array}$ & $\begin{array}{c}\text { Max. } \\
\text { breadth }\end{array}$ & Index $\mathrm{K}$ & $\begin{array}{l}\text { Index } \\
\mathrm{W}\end{array}$ \\
\hline Talpa europaea & 4 & $\begin{array}{l}0.7-4.4 \\
(202)\end{array}$ & $\begin{array}{l}0.1-0.9 \\
(0.56)\end{array}$ & $\begin{array}{l}.75-5.24 \\
(4.02)\end{array}$ & 17.0 \\
\hline Erinaceus europaeus & 30 & $\begin{array}{c}2.2-11.1 \\
(5.93)\end{array}$ & $\begin{array}{l}0.7-6.0 \\
(3.14)\end{array}$ & $\begin{array}{l}1.25-4.37 \\
(2.05)\end{array}$ & 9.7 \\
\hline Lepus europaeus & 5 & $\begin{array}{l}9.2-17.26 \\
\quad(10.84)\end{array}$ & $\begin{array}{c}2.9-6.0 \\
(4.09\end{array}$ & $\begin{array}{l}2.09-5.40 \\
(3.45)\end{array}$ & 7.2 \\
\hline Oryctolagus cuniculus & 3 & $\begin{array}{l}8.7-9.3 \\
(8.93)\end{array}$ & $\begin{array}{c}2.2-3.2 \\
(2.8)\end{array}$ & $\begin{array}{l}2.75-4.23 \\
(3.29)\end{array}$ & 7.0 \\
\hline $\begin{array}{l}\text { Sciurus vulgaris } \\
\text { (River Kolyma) }\end{array}$ & 39 & $0.6-7.5$ & $\begin{array}{l}0.2-4.0 \\
(1.42)\end{array}$ & $\begin{array}{l}0.91-5.77 \\
(2.25)\end{array}$ & - \\
\hline $\begin{array}{l}\text { Sciurus vulgaris } \\
\text { (Poland) }\end{array}$ & 10 & $\begin{array}{l}1.5-10.1 \\
(4.87)\end{array}$ & $0.8-6.0$ & $\begin{array}{c}1.41-2.78 \\
(1.93)\end{array}$ & 10.0 \\
\hline $\begin{array}{l}\text { Dyromys nitedula } \\
\text { (Białowieża Forest) }\end{array}$ & 21 & $\begin{array}{l}0.8-2.3 \\
(1.27)\end{array}$ & $\begin{array}{c}0.5-2.2 \\
(1.36)\end{array}$ & $\begin{array}{l}0.58-2.20 \\
(0.99)\end{array}$ & 19.0 \\
\hline $\begin{array}{l}\text { Dyromys nitedula } \\
\text { (remainder) }\end{array}$ & 49 & $\begin{array}{l}0.2-1.7 \\
(0.99)\end{array}$ & $\begin{array}{c}0.2-1.4 \\
(0.68)\end{array}$ & $\begin{array}{c}0.69-2.33 \\
(1.26)\end{array}$ & 24.0 \\
\hline $\begin{array}{l}\text { (remainder) } \\
\text { Rattus rattus }\end{array}$ & 11 & $\begin{array}{c}0.4-3.1 \\
(1.40)\end{array}$ & $\begin{array}{l}0.3-1.6 \\
(1.28 j\end{array}$ & $\begin{array}{c}0.71-3.0 \\
(1.42)\end{array}$ & 33.6 \\
\hline Microtus agrestis & 16 & $\begin{array}{c}0.6-2.6 \\
(1.37)\end{array}$ & $\begin{array}{c}0.1-1.4 \\
(0.48)\end{array}$ & $\begin{array}{l}1.47-5.50 \\
(3.06)\end{array}$ & 18.6 \\
\hline Microtus arvalis & 8 & $\begin{array}{c}0.4-3.3 \\
(1.17)\end{array}$ & $\begin{array}{c}0.1-1.2 \\
(0.3 b)\end{array}$ & $\begin{array}{l}2.50-13.00 \\
(5.51)\end{array}$ & 20.8 \\
\hline Sus scrofa & 3 & $\begin{array}{c}11.0-12.2 \\
(11.47)\end{array}$ & $\begin{array}{c}4.8-7.9 \\
(6.00)\end{array}$ & $\begin{array}{l}1.56-2.29 \\
(1.97)\end{array}$ & 27.4 \\
\hline
\end{tabular}

7. Dyromys nitedula ( $\mathrm{P}$ a 11 a s 1779). All the bones were found in the font. posterior. These are usually similar in form to an isosceles triangle or to a falling drop, when the side pointing to the back is convex in the interparietal direction (ratio of height to base $\mathrm{K}=0.99-1.26$ ). Extreme deviations include bony elements from those strongly elongated in the sagittal plane (hight and narrow) to completely flat "triangles" (wide and low). Only in two or three cases out of 65 were long and narrow bones 
fond, situated in sut. sagittalis above font. posterior. In certain individuals the Wormian bones were very small $(0.2 \times 0.3 \mathrm{~mm}$.) and they were then round or oval in shape.

The sutures separating the Wormian bones, like almost all the connections of the bones forming the brain-case of the forest dormouse, are straight and regular. The sutures separating the Wormian bones were not observed to coalesce, as was sometimes the case in other species.

In one case (no. coll. S-47257, LSU) a small bone was found lying separately within the limits of the interparietale, which was divided into two parts and, properly speaking, was not fused.

The dimensions of the Wormian bones and their proportions (Index K) in Dyromys nitedula are given in table 4. Two groups were distinguished here: a large series from the Białowieża Primeval Forest (both the part belonging to Poland and that belonging to the BSSR) and from the remaining areas. As in the case of $S$. vulgaris, here too differentiation is observed in the size of the Wormian bones. In individuals from the Białowieża Primeval Forest they are larger $(\mathrm{W}=19.0)$ than in areas situated more to the south $(\mathrm{W}=24.0)$.

8. Sicista betulina ( $\mathrm{P}$ alla s 1779). Sutural bones of small dimensions (about $0.9 \times 0.5 \mathrm{~mm}$.) were found in 3 individuals $(2.13 \%)$. In one case the bone was situated above the interparietale in the place where the sut. lambdoides and sagittalis cross. In the remaining two cases ( 2 bones and one bone) they lay in the bregmatic region.

9. Mus musculus Linna e us 1758. Bones in the house mouse occur very rarely ( 3 skulls out of 474 ) and were found both in the bregmatic region and in the font. posterior. Maximum size $-1.1 \times 0.6 \mathrm{~mm}$. In one case the presence of two bones was found, one lying in sut. sagittalis $(1.7 \times 0.3 \mathrm{~mm}$. $)$, the other towards the back in font. anterior $(0.68 \times 0.5$ $\mathrm{mm}$.).

10. Rattus rattus ( $\mathrm{L}$ in $\mathrm{n}$ a e u s 1758). The bones, fairly often observed in rats, differed in shape, similar to a triangle, elongated in the sagittal or transverse plane $(\mathrm{K}=0.71-3.0)$. They usually occur singly (only in one case - 3), in both fontanelles and also laterially from sut. sagittalis in sut. coronalis and parieto-interparietalis (fig. 1, 15-17). Their dimensions are relatively small, attaining a maximum of $3 \mathrm{~mm}$. The index of size $\mathrm{W}$ in 33.6 and is the highest in the material studied (Table 4).

11. Microtus arvalis (P a 11 a s 1779). Analysis was made of three series of common voles (Table 5).

It is clear from the table 5 that considerable differentiation is observed in $M$. arvalis between the various populations of this species. I am here thinking primarily of the results from Białowieża Glade and Polesie. 
Material from laboratory breeding cannot be taken into consideration, although it is the first or second generation obtained from initial material caught in the Wrocław district.

The Wormian bones in $M$. arvalis from Polesie take the form of elongated bones, the long axis of which may exceed the breadth by as much as 13 times (see Table 4), while the mean coefficient $\mathrm{K}$ is 5.51. These bones usually lie in the sut. sagittalis, at the level of or above sut. coronalis.

In one case the Wormian bone occupied the entire length of sut. sagittalis, between sut. parieto-interparietalis and sut. coronalis (Fig. 1, 13). Elements of different shape are sporadically observed, that is, oval, lying for instance in sut. coronalis, completely laterally in relation to the sagittal axis of the skull.

\section{Table 5.}

Comparison of percentages of individuals possessing Wormian bones from three populations of Microtus arvalis.

\begin{tabular}{|l|c|c|c|}
\hline \multicolumn{1}{|c|}{ Locality } & \multicolumn{2}{c|}{$\begin{array}{c}\text { No. of individuals } \\
\text { with Wormian bones }\end{array}$} \\
\cline { 2 - 4 } & $\mathrm{N}$ & $\mathrm{n}$ & $\%$ \\
\hline Białowieża Glade & 155 & 1 & 0.64 \\
Polesie (BSSR) & 141 & 8 & 5.67 \\
Wrocław (material from laboratory breeding) & 167 & 14 & 8.37 \\
\hline
\end{tabular}

The sutural Wormian bones in the series of $M$. arvalis from Wrocław were of a similar character, except that elements of oval shape occurred relatively more frequently, lying both in sut. sagittalis, in font. anterior and also in sut. coronalis.

The only case noted in material from Białowieża is particularly interesting (Fig. 1, 14), since here we have: a) 2 Wormian bones, similar in shape to a triangle, situated in font. posterior on each side of sut. sagit:alis; b) one bone, lying in the place where the abnormally non-fused suture between ossa interparietalia and sut. interparieto- occipitalis meet, almost within the area of the interparietal bone; and c) fontanelle situated anterior to this later bone. A triple anomaly can therefore be observed here: the presence of supernumerary bones, the occurrence of a suture which is additional in a grown individual, and which usually ossifies during embryonic development, and a fontanelle which has failed to close over.

12. Microtus agrestis ( $\mathrm{Lin} \mathrm{n}$ a e us 1761). In the field vole sutural bones occur in a small number of specimens $(1.8 \%)$ and always lie in the 
bregmatic region, in sut. sagittalis. They usually take the form of greatly elongated bones ( $\mathrm{K}=3.06$, in extreme cases up to 5.50 - table 4$)$, with sharp terminals at both ends. The greater part of the bone then lies anterior to sut. coronalis. In more or less $1 / 3$ of all cases these bones take the shape of elongated rhombs $(K=2.0-2.8)$ with unequal sides. They may be situated anterior or posterior to sut. coronalis, with all the intermediate stages.

In the vast majority of cases we are concerned with bones occurring singly. Only in two specimens were paired elements found, lying on each side of sut. sagittalis.

13. Microtus oeconomus ( $\mathrm{P}$ a $1 \mathrm{l}$ as 1776). The Wormian bones in the root vole are of the same character and dimensions as those of the above-mentioned two representatives of the genus Microtus S ch ra n k 1798 .

14. Sus scrofa Linn a us 1758 . Sutural bones were observed in two individuals out of 90 examined $(=2.22 \%)$. In both cases they lay in sut. sagittalis between ossa parietalia. In individual no. coll. 90 - one piriform bone was found, in no. coll. 3 - two bones in the form of rhombs, with rounded angles and unequal sides. The dimensions of these are given in table 4 . The sutural bones of wild boar are among the relatively smallest (index $\mathrm{W}=27.4$ ).

15. Carnivora. Tracing of the Wormian bones in this group of mammals is especially difficult on account of the very early ossification of sutures in post-natal development, the formation of crests etc. In the material, composed of juvenile animals, to which I had access, I found in Canis lupus $\mathrm{L}$ in $\mathrm{n}$ a e u s 1758 the presence of a small, triangular and elongated bone in font. posterior, inserted like a wedge in sut. sagittalis. Bones of similar shape, the sharp end of which was pointing to the front, wert found in 2 young specimens of Mustella putorius L in na e us 1758 . In both cases they lay in the suture between ossa nasalia.

Two general conclusions are clear from the above review of different species.

In the majority of the mammals examined the Wormian bones are single elements, situated centrally or asymmetrically. They are not infrequently found in larger numbers $(2-3)$ and may then lie on each side of the sagittal axis of the skull. In the small rodents and insectivores analysed here this is somewhat of a rare occurrence, being more often encountered in larger mammals (e.g. L. europaeus, Sus scrofa, cf. also S c hult z's data, 1923).

The shape of the Wormian bones in certain species is fairly constant (Dyromys nitedula, Microtinae) while in others it is very variable (E. eu- 
ropaeus, Sciurus vulgaris). This is undoubtedly accounted for by their different situation in the skull and tendencies in the given species for the respective sutures to coalesce. Additional bony elements in sut. sagittalis usually take the shape of elongated bones. When they lie in the fontanelle they more resemble ovals, rhombs or triangles.

The dimensions, proportions and relative size of Wormian bones are subject to considerable variations in different species of mammals, and also to wide individual variation (Table 4).

\section{OTHER ANOMALIES OF THE SUTURES OF THE BRAIN-CASE}

1. Os interparietale. It is a known fact that this bone in rodents is relatively large and is formed during embryonic development from two elements, which in the early stages unite in the unpaired bone found in adult animals. When analysing material from the aspect of occurrence of Wormian bones I found that in certain species of rodents, a distinct suture is sometimes maintained, running in the sagittal plane and dividing this bone into two parts. This anomaly occurs relatively seldom and was observed in Eliomys quercinus, Glis glis - single cases, Dyromys nitedula in 5 specimens, Sicista betulina - in 3, Apodemus agrarius - in 2, from among the total numbers of skulls examined, given in table 1.

2. Fontanelle. In many of the species I also encountered cases in which the fontanelles had failed to close. They were usually maintained in the same places in which the Wormian bones normally occur (e.g. in L. europaeus, M. musculus, M. agrestis), in two cases even in addition to the already existent bones ( $L$. europaeus, $M$. arvalis) - Fig. 1, 10, 14).

As a rule single fontanelles were situated in the bregmatic region. Paired ones (M. agrestis, $S$. betulina) lay laterally on both sides of the sagittal suture. Such fontanelles are observed in a joint total of 8 completely grown individuals belonging to the 5 species referred to above. They are most often encountered in $M$. agrestis, where they form $3 \%$ of the specimens $(\mathrm{N}=302)$.

\section{DISCUSSION OF RESULTS}

The Wormian bones may be formed from a connective tissue or enchondral basis. They are found both in sut. sphenoethmoidalis and between the supraoccipitale and exooccipitale (De B e e r, 1937). Virk ki (1954) summing up the data given by former authors such as M a ti e gk a (1905), B olk (1913), V itols (1930) who investigated embryonic material, states that additional centra of ossification may occur in the fontanelles, fusing with continued development with the bones of the brain-case. They may also unite with each other and form the beginning of separate, additional bony units - sutural and bregmatic bones. De $\mathrm{B}$ e e $\mathrm{r}$ (1937) is of the opinion, however, that the more frequent way in which Wormian bones are formed is the separation of small islets from the normally developing bones of the brain-case. He assumes that this is 
connected with the stretching of the dura mater on the intensively growing brain. This idea has its origin in an analysis of the structure of hydrocephalic skulls and would not appear to be acceptable as a general principle applying to all groups of mammals. The process of stretching of the dura mater probably takes place in shrews (Sorex Linna e us 1758) in which the intensively enlarging brain in the spring as it were "bursts" the skull. The sutures - sut. sagittalis and sut. lambdoides loosen and a new osseous tissue grows up on the margins of ossa parietalia and occipito-interparietale, filling the free space between the above bones and leading to complete closing (but not to ossification) of the sutures (P u c e k, 1955; 1957; C a b oń, 1956; B i e la k \& P u c e k, 1960). The separation of small bony elements which might possess the character of Wormian bones was not however observed in these animals.

Supernumerary bones in the skulls of different species of mammals occur irregularly, both as regards frequency and situation. It is therefore not possible to attribute to them any philogenetic or taxonomic importance. The shape and dimensions of the Wormian bones are very variable, both in different forms and in representatives of the same species. I also found considerable differences in the concentration of this feature in different populations, more or less distant from each other, of the given species (e.g. D. nitedula, M. arvalis). It would seem that they may be differences genetically consolidated, or brought about by the specific nature of the given habitat. If we accept the existence of a genetic basis determining a defined degree of concentration of this feature in populations of the given species, then under the actual conditions in a certain area, congregation of individuals possessing Wormian bones may take place. I am here thinking of the phenomenon of fairly regular revival of a population from the few individuals which remained after a depression in numbers and which were characterised by, for instance, presence of sutural or bregmatic bones.

Similar suggestions were put forward in the work by $\mathrm{M} \mathrm{a} \mathrm{k}$ a r z e c \& $\mathrm{F}$ a r bis zew ska (1960) in relation to the simplex form in $M$. arvalis. In such a case, however, the irregular distribution of this feature might be expected within the geographical range of the given species, as observed in the case of $S$. vulgaris. In other cases (Dyromys nitedula) however, a fairly regular decrease in concentration of individuals with Wormian bones is found in the north to south direction. Here again the really strinking similarity to $\mathrm{Z}$ i $\mathrm{mm}$ e $\mathrm{rm}$ a n's rule becomes apparent with regard to the occurrence of the simplex form in M. arvalis (!). It is possible that we are concerned here only with random disposition of material, or with real differentiation in the occurrence of Wormian bones in different parts of the geographical range of forest dormice. To a cer- 
tain extent this would confirm Manvill e's data (l.c.) on Lynx rufus. On account of the none too numerous series of material, however, it is not possible to supply an answer to the question as to whether this phenomenon is of a more general character and applies also to other species of mammals, or is a feature proper to certain forms only.

A group of species (Microtinae) differentiated itself from the rest of the material examined by having a relatively constant type of structure of sutural Wormian bones with more or less uniform localisation. It is, however, necessary to exercise great care in generalising on the basis of this conclusion in relation to all representatives of this sub-family.

On the basis of the factual material given and data from literature referring to a total of over 50 species of mammals, it is not at present possible to determine regularities in the occurence, shape and dimensions of Wormian bones.

The fact is surely of significance that in certain species of mammals the Wormian bones have not as yet been examined at all. In literature we find very few data on this subject ( $\mathrm{Sch} \mathrm{ultz}, 1923$; V i r k k i, 1954) despite the fact that such findings are of real importance to the problem as a whole. It would seem that lack of occurrence of bregmatic bones may take place in all groups of mammals (cf. comparison in table 1). This is undoubtedly connected either with the very rare appearance of these elements (below 1 and even $0.25 \%$ ) or with the definite mechanical-physiological properties of the skull of these animals (e.g. C. suslicus, Pteromys volans, M. avellanarius, A. flavicollis, A. terrestris). In certain cases, such as Citellus, Pteromys, there are simply no mechanical means by which such bones might be observed. The majority of the sutures undergo ossification in the early stage of ontogenetic development. Thus, in order to discover whether these elements form at all, we should have to go as far back as the embryonic development of these species. The data obtained for adult animals in such cases can therefore only be considered as a guide. I am of the opinion that in many cases both parts of the alternative put forward previously contribute to the absence of Wormian bones in the adult specimens of these species.

In the light of data so far obtained it is not possible completely to explain the causes of the formation of Wormian bones. Regardless of whether we connect them with factors of a genetic nature (K e eler, 1933) or whether we consider the Wormian bones as a certain developmental deviation expressed in irregularity of ossification of the brain case, we shall be obliged, in order to explain their genesis, to make rigorously conducted experiments on culture material of different mammals with genetic equality. 


\section{SUMMARY}

Analysis was made of the occurrence of sutural and bregmatic Wormian bones in 6564 specimens belonging to 28 species and 5 orders of mammals.

Wormian bones were found only in certain species. Presumably this is connected with the morpho-functional properties of the skull and the earlier or later ossification of fontanelles and sutures during ontogenetic development.

The percentage of individuals with Wormian bones varies in different species and fluctuates from 0.6 in M. musculus to 58 in $E$. europaeus. Considerable variation was observed in the concentration of this feature in different populations of the same species (e.g. S. vulgaris, D. nitedula). In the latter case it was found that in the northern parts of their geographical range the percentage of individuals with these bones is the greatest $\left(69^{\%} \%\right)$ and that it gradually decreases with passage southwards, in extreme cases being below $4 \%$ (and even $0 \%$ ).

In the majority of species the Wormian bones occur in the form of single elements situated centrally or asymmetrically. If there is more than one in skull $(2-3)$ they may lie on each side of the medial plane of the skull.

Despite the fact that up to the present examination has been made of over 50 species of mammals (author's data and data from literature) it is impossible to establish any general regularities in occurrence, shape and dimensions of the Wormian bones. In some species (Dyromys nitedula, Microtinae) their shape is relatively constant, in others very variable ( $S$. vulgaris, E. europaeus). It is possible that this depends on the localisation of the bones in the skull (font. anterior, font. posterior, sut. sagittalis, coronalis, lambdoides). Absolute and relative dimension (in relation to $\mathrm{Cb}$.) are subject to considerable individual variation and variation from species to species. In view of such extensive variability it is probably impossible to attach any philogenetic or taxonomic importance to these elements.

In addition the author describes other anomalies of the skull, such as failure to coalesce of ossa interparietalia and the continuation of the fontanelles in fully grown individuals.

\section{REFERENCES}

1. De B e e r, G.: 1937: The development of the vertebrate skull. Clarendon Press, Oxford, pp. $1-552+$ XXIII.

2. Bi elak, T. \& Pucek, Z., 1960: Seasonal changes in the brain-weight of the Common shrew (Sorex araneus araneus Lin n a e $\mathrm{s}$ 1758). Acta theriol., 3, 13: $297-300$, Białowieża.

3. C a b o ń, K., 1956: Untersuchungen über saisonale Veränderlichkeit des Gehirnes bei der kleinen Spitzmaus (Sorex minutus minutus L.). Ann. Univ. M. Curie-Skłodowska, C 10, 5: 93-115, Lublin.

4. K e ele r, C. E., 1933: Interfrontal - a heritable cranial variation of the house mouse J. Mammal., 14: 75-76 (acc. to V ir k k i, 1954).

5. Kopsch, F., 1955: Rauber-Kopsch Lehrbuch und Atlas der Anatomie des Menschen. G. Thieme, Stuttgart, 1: $1-736+$ VII:

6. Farbiszewska, J. \& Makarzec, B., 1960: Gebissvariabilität bei Microtus arvalis (P a 11 a s 1779) in Ost-Polen. Acta theriol., 3, 13: 302-307, Białowieża.

7. M a nville, R. H., 1959: Bregmatic bones in North American Lynx. Science, 130 (3384): 1254. Washington. 
8. M ül1 e r, M., 1937: Über Ossa Wormiana parieto-occipitalia beim Pferd. Anat. Anz., 85, 7-8: 129-139.

9. Poplewski, R., 1948: Anatomia ssaków. Czytelnik, Stockholm, 2: 1-690 VIII.

10. Pucek, Z., 1955: Untersuchungen über die Veränderlichkeit des Schädels im Lebenszyklus von Sorex araneus araneus L. Ann. Univ. M. Curie-Skłodowska, C 9, 4: 163-211. Lublin.

11. Pucek, Z.: 1957: Histomorphologische Untersuchungen über die Winterdepression des Schädels bei Sorex L. und Neomys K a u p. Ibid., C 10, 15: 399-428.

12. Schultz, A. H., 1923: Bregmatic fontanelle bones in Mammals. J. Mammal., 4, 2: $65-77$.

13. Virkki, N., 1954: Über den Schaltenknochen der Bregmagegend beim Eichhörnchen, Sciurus vulgaris L. Arch. Soc. "Vanamo", 9, 2: 100-108. Helsinki.

14. Virkki, N., 1956: Bregmaknochen im Schädel nordamerikanischen Eichhörnchen. Ibid., 11, 2: 187-188.

15. Zimmermann, K., 1935: Zur Rassenanalyse der mitteleuropäischen Feldmäuse. Arch. Naturgesch., 4. Leipzig.

Polish Academy of Sciences, Mammals Research Institute,

Białowieża, woj. Białystok.

\section{STRESZCZENIE}

Przeanalizowano występowanie szwowych i ciemiączkowych kostek Worma u 6564 okazów, należących do 28 gatunków i 5 rzędów ssaków.

Kostki Worma stwierdzono tylko u niektórych gatunków. Przypuszczalnie jest to związane $\mathrm{z}$ morfofunkcjonalnymi właściwościami czaszki oraz weześniejszym lub późniejszym w rozwoju ontogenetycznym kostnieniem ciemiączek i szwów.

Procentowy udział osobników z kostkami Worma jest zmienny u różnych gatunków i waha się od 0.6 u M. musculus do 58 u E. europaeus. Obserwowano dużą zmienność w koncentracji tej cechy w różnych populacjach tego samego gatunku (np. S. vulgaris, D. nitedula). W tym ostatnim przypadku stwierdzono, że w północnych partiach areału geograficznego udział osobników z kostkami jest największy $\left(69^{\%} \%\right)$ i stopniowo maleje w kierunku na południe, wynosząc skrajnie poniżej $4^{\%} \%$ (a nawet $0 \%$ ).

U większości gatunków kostki Worma występują w postaci elementów pojedyńczych, położonych centralnie lub asymetrycznie. Jeżeli jest ich więcej w jednej czaszce $(2-3)$ mogą leżeć po obu stronach płaszczyzny pośrodkowej czaszki.

Mimo, że przebadano dotychczas (dane autora i z literatury) ponad 50 gatunków ssaków, nie można ustalić żadnych ogólnych prawidłowości dotyczących wystęoowania, kształtu i wymiarów kostek Worma. U jednych gatunków (Dyromys nitedula, Microtinae) kształt ich jest względnie stały, u innych zaś bardzo zmienny (S. vulgaris, E. europaeus). Być może jest to uzależnione od miejsca położenia kostek w czaszce (font. anterior, font. posterior, sut. sagittalis, coronalis, lambdoides). Wy- 
miary absolutne i względne ( $\mathrm{w}$ stosunku do $\mathrm{Cb}$.) ulegają dużej zmienności indywidualnej i u poszczególnych gatunków. Wobec tak szerokiej zmienności elementom tym nie można chyba przywiązywać jakiegokolwiek znaczenia filogenetycznego czy taksonomicznego.

Poza tym autor opisuje inne anomalie czaszki, jak niezrastanie się ossa interparietalia oraz utrzymywanie się ciemiączek u osobników w pełni wyrośniętych.

PANSTWOWE WYDAWNICTWO NAUKOWE * WARSZAWA 1962

Nakład 1450 egz. Obj. ark. wyd. 1.5, druk. 1.25. Maszynopis otrzymano 16.IV.1962. Podpisano do druku 26.VI.1962. Druk ukończono

3.VII.1962. Papier druk, sat. III kl. 80 g. Format B5. Cena 6 zl.

Bialostockie Zakłady Graficzne. Zam. 1573. F-2 